\title{
The Challenges Facing the Integration of ICT in Teaching and Learning Activities in South African Rural Secondary Schools
}

Mlunghisi D. Mathevula

University of Limpopo

Email: mdmlunghisi@gmail.com

\section{Dominique E. Uwizeyimana}

University of Johannesburg

Email: Uwizeyimanadde@yahoo.com

Doi:10.5901/mjss.2014.v5n20p1087

\begin{abstract}
The objective of this quantitative study was to investigate the impact of ICT equipment availability and accessibility and teachers' training in ICT use on the integration of ICT into the curriculum related activities by teachers. The data used in this research was collected by means of structured questionnaires, from 146 participants in twelve secondary schools located in the Groot Letaba Circuit, Mopani District Municipality in Limpopo Province, South Africa. The findings reveal that, with the exception of a TVs, photocopiers and laptop/desktop computers, there is a scarcity of ICT resources available at schools for ICT integration, and that the teaching and curriculum administration functions of most teachers have been negatively impacted by a lack ICT equipment and/or insufficient use of these ICT resources for those schools who have them. In addition, while some teachers had received some form of ICT training, it was evident that such training has had minimal or no impact at all on the abilities and confidence of teachers to use ICT in their teaching. These factors that negatively influence teachers' readiness for, and confidence in, using ICT; need to be dealt with by the various stakeholders including, and especially, the Department of Education and the school management and private partners.
\end{abstract}

Keywords: ICT integration, Teaching and Learning, E-education, E-learning

\section{Introduction}

During the past decade a great deal of literature has been produced on the use of Information and Communication Technology ((thereafter ICT) in schools (Summak \& Samancioglu, 2011; Goyal, Purohit \& Bhaga, 2011). The ICT refers to the hardware, software, networks and media for the collection, storage, processing, transmission and presentation of information (voice, data, text, images), as well as related services (Evoh, 2007:1). Perron, Taylor, Glass \& MargerumLeys (2010:67) describe the extent of the uses of ITCs in the following terms:

"Information and communication technologies (ICTs) are broadly defined as technologies used to convey, manipulate and store data by electronic means. This can include e-mail, SMS text messaging, video chat (e.g., Skype), and online social media (e.g., Facebook, mixit). It also includes all the different computing devices (e.g., laptop, desktops and smart phones) that carry out a wide range of communication and information functions. All these electronic tools constitute the "Information and communication technologies" (ICTs) and are used to convey, manipulate and store information (Perron, et. al. 2010:67).

The existence of a wide variety of ICTs suggests that ICTs go far beyond computers and the internet or even telephony (Perron, et. al. 2010). However, owing to the fact that this research was conducted in a developing country, namely South Africa, where schools, especially those in rural areas are still struggling to get even the basic infrastructure, the types of equipment that are the focus of this research are: computers (desktops, laptops), photocopy machines, data projectors, interactive whiteboards, Word Processing, Internet, digital cameras, television (TVs), CD/DVD Players, radios and tape recorders. Other types of ICT equipments are referred to as and when the context requires doing so.

A review of literature suggests that there has been an exponential growth in the use of information and communication technology (ICT) in education in developed countries (Allan, Yuen \& Wong, 2003:158). However, while ICTs are pervasive in developed countries, their use has been and remains in a state of fluidity and their integration into the school curriculum remains significantly underdeveloped in developing countries (Isaacs, 2007:1). It is highly ironic that 
this should be so in the $21^{\text {st }}$ century, an era of information technology (IT). This quantitative study seeks to investigate the availability and accessibility of ICT equipment and the impact of training in ICT use on integration of ICT into the curriculum related activities by teachers in selected participating secondary schools.

\section{Literature Review}

This section looks at the different views about the impact of ICT on teaching and learning and the common obsticles to ICT integration in teaching and learning in different contexts.

\subsection{Impact of ICT on teaching and learning}

There is not yet, a concensus in the literature as to the impact of ICT on teaching and learning. Some, such as Newton \& Rogers (2001:18), argue that even after some years of ICT utilisation and research into its effects, there is still some uncertainty over its educational merits and demerits. Firstly, as Mikre (2011:13) argues, there is a danger that students may be confused by the multiplicity of available information from which to choose. Secondly, the prevalence of undesirable websites poses a real threat as learners tend to spend most of their lerning time on websites containing unsolicitated contents, such as pornographic material as they seek to explore the Internet (Devadason, 2010). The prevalence of undesirable websites is a genuine and critical concern that could affect learning and teaching because the teacher has to spend much time trying to control students from using websites unrelated to the learning content, instead of teaching (Mikre, 2011:13). These challenges bring into question the issue of security, not in terms of physical security but in terms of access to information security. Thirdly, the openness of the web puts students into an exploratory mode which often challenges effective learning in time-constrained formal school systems (Devadason, 2010:14). Without teachers' supervision, it is possible that students might misuse the technology for leisure time activities and have less time to learn and study (Mikre, 2011:12). Yousef and Dahmani (as quoted by Mikre, 2011:12) list online gaming, use of Facebook, chat rooms and other communication channels as some of other the perceived drawbacks of ICT use in education, because students easily switch to these sites at the expense of their study. It is also possible that the use of ICT to access website with unsollicitated and harmful content may lead some students to develop unti-social behaviour (such as promiscuity, violence, Satanism etc.) as some learners tend to imitate whatever they watch on these websites. In addition to unti-social behaviour, Mikre (2011:13) identifies the following major problems associated with the ICT use in education as related to students' learning:

- 'Over-reliance on ICT limits students' critical thinking and analytical skills,

- Students often have only a superficial understanding of the information they download,

- Computer-based learning has negative physical side-effects such as vision problems,

- Students may be easily distracted from their learning and may visit unwanted sites,

- Students tend to neglect learning resources other than the computer and the Internet,

- Students tend to focus on superficial presentations and copy from the Internet,

- Students may have less opportunity to use oral skills and hand writing,

- Use of ICT may be difficult for weaker students, because they may have problems with working independently and may need more support from the teacher" (Mikre, 2011:13).

However, while Kozma (2003) found a negative relationship between the frequency of use of computers and school achievement, others, such as Isaacs (2007) found growing evidence to suggest that the use of ICTs may actually be the only feasible and economically sound means of expanding access to, and improving the quality of, secondary school education in the short run. Others such as Peter (2010) found several rationales, namely economic, social, vocational and pedagogic for the uptake of ICT in education. According to Peter (2010), the economic rationale of ICT in education relates to potential increase of efficiency and effectiveness in educational tasks, which will result in laboursaving costs. Pedagogic rationale on the other hand "emphasises the contribution that ICT can make to the improvement of the quality of education by providing rich, exciting and motivating and new environments for learning" (Peter, 2010:10). Social rationale, according to van Ark (2011:6), focuses on the social aspects and benefits of ICT. Others who found a positive impact of ICT on teaching and learning include Balanskat (2007:16)'s study which found that $79 \%$ of teachers believe that using computers in class has a significant impact on learning, while only $21 \%$ of them believe it does not. However, it is Kulik's (1994) research findings (quoted by Mikre, 2011) which provides arguably the best summary of impact of ICT usage in teaching and learning. Kulik's research findings show that students who used computer tutorials in mathematics, natural science, and social science score significantly higher on tests in these subjects (see Mikre, 2011:3). Kulik (1994:9-34)'s findings also indicated that: 
"Students who used simulation software in science also scored higher. Primary school students who used tutorial software in reading scored significantly higher on reading scores. Very young students who used computers to write their own stories scored significantly higher on measures of reading skill, and students who used word processors or otherwise used the computer for writing scored higher on measures of writing skill" (Mikre, 2011:3).

Benefits from the utilisation of ICT in teaching and learning have also been reported by Newman (2002) and Wheeler (2000) who argue that the benefits include shared learning resources, shared learning spaces, the promotion of collaborative learning and the move towards autonomous learning. In terms of sharing learning resources, according to Newman (2002), ICT has the potential of enabling students and teachers to use video systems to transmit television programmes and information throughout an entire school and even between schools in the same district. In turn, sharing learning resources has the potential of minimising costs and improving the quality of teaching and learning, especially in under-resourced schools (Newman, 2002). In terms of shared learning spaces, networked computing facilities create a distributed environment where learners can share work spaces, communicate with each other and their teachers in text form, and access a wide variety of resources from internal and external databases via web-based systems through the Internet (Wheeler, 2000). Sharing learning space could go a long way in reducing the problems of over clouding and lack of teachers which are said to be at an alarming stage, especially in rural areas schools of some developing countries such as South Africa (Mdletshe, 2013). In terms of "Promoting collaborative learning", Riel (2000, cited in Wheeler 2000:2), argues that the use of ICT will make it possible for much of what we now see as individual learning to change and become collaborative in nature. Furthermore, in terms of ICT facilitating the move towards autonomous learning, computers - and the power they bring to the student to access, manipulate, modify, store and retrieve information - will promote greater autonomy in learning (Wheeler, 2000). In turn, such students' learning autonomy will enable children to exert more choice over how they approach study, requiring less direction from teachers. This is no way to imply that ICT is going to replace teachers. However, as students become increasingly independent and able to direct their own studies to a greater extent, the teacher's role will become more and more "a guide or moderator rather than as a director" (Forsyth, 1996:31). Thus, ICTs can act as an agent for change (Beyers, 2000:52) by significantly enhancing educational reform which enable teachers and learners to move away from traditional to more innovative and effective approaches to teaching and learning (DoE, 2003). Thus, among the multifaceted benefits of using ICTs are also that they motivate pupils, provide variety, compensate for language deficiency, encourage active participation, reinforce learning, increase application possibilities, enhance the applicability of the learning content provided for the learning needs of individuals pupils, and supplement the spoken word (Kruger, 2010).

Finally, a careful deployment of ICTs can go a long way in bridging both the quantitative (access) and qualitative (standard) gaps in secondary education because ICTs could be used to make education accessible to more learners (Evoh, 2007:10-11). The deployment of ICTs in secondary schools, including training of teachers in the use of ICTs, could, also enable South Africa (a country with huge inequalities between the rich and the poor, between the rural and urban areas' access to services, especially ICT) to utilise the existing limited resources, including teachers, more effectively to accomplish the goals of improved secondary education and human resource development (Evoh, 2007:8). However, in order to achieve this, according to Beyers (2000), schools with one PCs must be shown how to use their meagre resources more effectively while schools with more ICT resources must be empowered to remove the control of these resources from the computer science departments so that more learners can benefit (Beyers, 2000). The question then is, if ICTs are likely to improve or contrinute to the improvement of teaching and learning, and even achieve some extra- socio-economic and pedagogic benefits in society, why there has been slow integration of ICT in schools?

\subsection{Common obstacles to successful ict integration in schools}

According to Bingimlas (2009:235) the act of integrating ICT into teaching and learning is a complex process and one that may encounter a number of difficulties. Literature tends to highlight amongst others, the following as being the common obstacles to successful ICT integration: lack of teacher confidence, lack of teacher competence, lack of effective training, resistance to change and negative attitudes, lack of technical support and lack of infrastructure (Korte \& Hüsing, 2007). These challenges are summarised in Figure 1 and each one of them is briefly discussed below. 
Figure 1: Factors that affect the integration of ICT

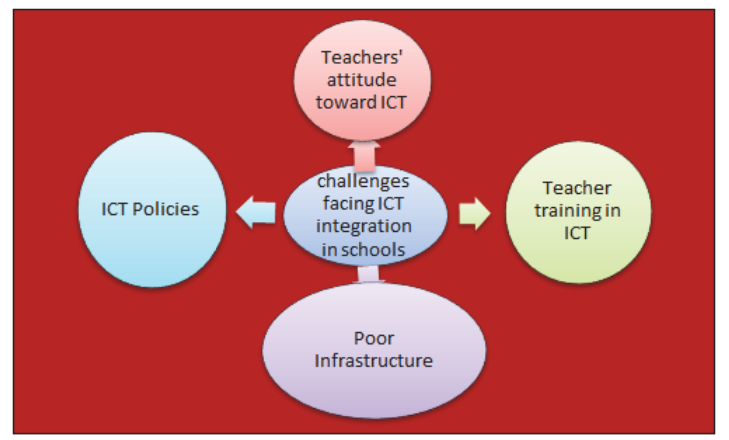

Sources: Adapted from Korte \& Husing, 2007

\subsubsection{Teacher training in ICT}

Naturally the use of ICT in teaching, learning and managing educational institutions, just like any other innovation, compels the emergence of a new set of skills, attitudes and pedagogical approaches that requires continuous training programs to build sufficient capacity among teachers, developers, educators and administrators (Rwanda Ministry of Education, 2008). This means that, while most schools (especially in developed countries, and relatively in urban areas of developing countries) are now equipped with computers, Internet access and occasionally more sophisticated equipment such as interactive whiteboards and effective e-Learning requires far more than the mere introduction of hardware in the classroom (van Rij \& Warrington, 2010:8). For these ICT equipments to mean anything, teachers must be conversant in utilising them to implement an integrated approach in ICT use and new approaches (Bialobrzeska \& Cohen, 2005:99). Thus, in view of the current scenario characterised by lack of capacity, there is a heightened need to fast-track the training of teachers (Beyers, 2000:52).

Some of the South African Government initiatives to deal with ICT training for teachers include the nine centres being established in each of the provinces as part of the Vodacom Mobile Education Programme. This type of ICT education centre for teachers is the realisation of a partnership formed between Vodacom and the Department of Education in order to help boost teacher training across all nine provinces of South Africa (Ayemoba, 2013). It is the intention of the programme to train about 1400 teachers annually in the use of ICT to support teaching and learning, focusing in mathematics and science subjects. Additionally a number of teachers from rural areas of South Africa are continuing to benefit from the "Train the Trainer" Project which has been initiated by the Internet Service Providers' Association of SA (ISPA) since 2001. The initiative is said to have already provided ICT skills training to more than 2000 teachers across South Africa since its inception in 2001. A large part of the initiative targets schools in under-resourced and rural areas and is set to deliver beginner and intermediate level courses (ISPA, 2011:1). There is, however, a concern that these initiatives focus on beginners and intermediate computer skills without equipping teachers with the necessary skills to benefit fully from ICT usage ((Miller, Naidoo \& Van Belle, 2006:11). Such skills should include evaluation of material found on websites: "How to make educationally appropriate use of resources for learning, including how to develop visual literacy skills, adapt material, design differentiated activities using the same resources and develop material" (Bialobrzeska \& Cohen, 2005:111). Finally, because of continuing changes in the technology sector, teachers need to be lifelong learners to keep themselves updated with the changes in technology and new teaching methods.

\subsubsection{Teachers' attitude toward ICT}

Mikre (2011:12) and Oladosu (2012) assert that teachers' attitudes play an important role in the teaching-learning process that utilises computers and Internet connections. Unfortunately, according to Wheeler (2000:3), whilst some have passionately integrated technology (such as computers), others have guardedly welcomed it whilst others have outrightly rejected it (Wheeler, 2000:3). The resistance in the acceptance of ICT in the classroom is often said to be primarily based on the "risk of teachers losing influence over the values and directions of classroom activity" (Chan, 2003:36). However, it is very important; to note that resistance to change is not necessarily a barrier in itself but could also be an indication of 
the presence of a much deeper problem (Bingimlas, 2009:238). This deeper problem as espoused by Cox et al (1999) appears to be the lack of the necessary knowledge, skills and attitude (SKAs) to adapt to the changes which will necessarily be brought in education by technology. Thus the motivation and confidence to integrate ICT in teaching and learning could only come from having access to ICT equipment and possessing the required ICT skills (Mikre, 2011:12). Finally, according to Buabeng-Andoh (2012) and Yuen et al (2003:168) "the leadership role of individual schools also plays an equally important part in shaping the responses to ICT innovation".

\subsubsection{ICT Policy issues}

According to the South African Information Technology Industry Strategy (SAITIS) (2002:14), South Africa does not have a comprehensive ICT policy. The legislative provisions are scattered throughout the government departments (SAITIS, 2002:30). There is a view that the absence of such a comprehensive policy is not the result of a lack of political will but is "the result of the speed with which developments occurs in the sector and the complexity of the issues involved" (SAITIS, 2002:5). Nevertheless, this situation has the potential to create conflict and detract government from pursuing a universal approach to ICT integration in South Africa (SAITIS, 2002). Thus the silo (i.e. fragmented) approach to the sector needs to be reviewed so that the South African Government does not inadvertently create a digital divide where access to quality communications services, technologies, infrastructure and content is a privilege of the elite, rather than a right for all (Department of Communications, 2013:10). Such weaknesses are also acknowledged in the National Development Plan (NDP) where it is states that, government should conduct a full policy review in the short term in order to develop a "new integrated policy" (Department of Communications, 2013:11). Ngcaba (2012:8) contends that the development of such a new policy paradigm "is aimed at ensuring that South Africa repositions itself as a leader in the ICT sector on the continent, serving as an example of visionary and enabling policy development and implementation". Although the NDP proposed an integrated ICT legislative and policy framework, the provision of ICT remains the responsibility of the Department of Communications, and various government departments are still directly responsible for operationalising their own policies.

\subsubsection{Poor infrastructure}

Apart from teachers' lack of capacity and attitude toward ICT usage, poor infrastructure remains a major obstacle in many developing states (Howie, Muller \& Paterson, 2005). For example, according to Makewa, Meremo, Role \& Role (2013:54), a survey in the USA by the National Centre for Education Statistics (NCES) in 2000 using the Fast Response Survey System (FRSS) revealed that $99 \%$ of full-time regular public school teachers had access to computers or the Internet somewhere in their schools. This is still a dream in many developing countries such as South Africa. Nonetheless, many countries (including developing countries such as South Africa) have increased the number of computers in schools in recent years or have plans (such as the Teacher Laptop Initiative in South Africa and Kenya) to increase teachers' and learners' access to computers (Kargiban \& Siraj, 2009:147). Managed by the Education Labour Relations Council (ELRC), the Teacher Laptop Initiative (TLI) aims at improving Information and Communications Technology (ICT) in teaching and learning and aims to ensure that more than 350000 government school teachers in South Africa own and use a laptop, by providing them with a monthly allowance which will cover the purchase costs as well as the costs of connectivity (ELRC Annual Report, 2010/11). Lounched in 2009 by the then Minister of Education, Naledi Pandor (2004-2009), the TLI was supposed to have completed the distribution of laptops to all qualifying teachers by the end of 2011 (Tubbs, 2013:1), but because of funding problems and the the fact that about 174000 teachers of about 380000 who are permanently employed nationally, are either blacklisted or not credit worthyl (Maluleka, 2011), this objective has still not been achieved by 2014. However, even if it is completed, there is no guarantee that most rural are schools will reap the benefits of these laptops because of lack of internet or prohibitive and exorbitant costs of internet for schools who have access to it or just because of teachers' lack of the necessary skills to use them. According to Farrell \& Isaacs (2009:19), because of prohibitive Internet costs in South Africa, of the estimated 6000 schools that have access to PCs, only an estimated 2500 have Internet access but even a lesser number of schools is able to use internet because government has been slow in implementing the e-rate policy. Started in the USA, "e-rate" is at its simplest a nationally agreed upon discounted rate for Internet access for schools: often this rate is included in the relevant telecoms legislation at a national level and therefore the responsibility of the regulator (Espitia and School Net Africa, 2013:1). If implemented, the e-rate would allow public schools a 50\% discount on calls to access the Internet as well as Internet access charges (Espitia and School Net Africa, 2013:1). 


\section{Research Methodology}

The research population comprises a total of 222 people from the twelve secondary schools in Groot Letaba Circuit of Mopani district in the Limpopo Province, South Africa. The names of the schools are withheld and are replaced with alphabet pointers in this research because of ethical and confidentiality concerns. Although there cannot be teaching if learners are not present, learners and members of governing bodies fall outside the scope of this research. Groot Letaba Circuit area is primarily rural and some schools are in the farming areas. All of the schools in the study area fall under Quintile one - the Department of Basic Education's classification category for no fee paying schools, due to the high poverty level of the residents of the area in which the school are situated. There are no private/independent schools i.e. schools that are privately owned, governed and funded (DBE, 2012:11) in this circuit. There is a general consensus that the larger the sample the more the results of the study would represent the entire population, and that if time and cost allows, it would be better to study the entire population (Mugo, 2002:2). Thus the intention of the researcher was to solicit responses from as many secondary school teachers (from Grade 8 to Grade 12) and principals as possible from these twelve schools in the Groot Letaba Circuit. As a result, a total of 146 respondeds (out of 222 possible participants) were randomly selected and agreed to participate in the research. For a sample to be deemed appropriate, the researcher should select a minimum of 10\% of the given research population (Babooa, 2008:144). Thus, 146 participants out of a total number of 222 school teachers and principals who participated in this research represented $66 \%$ of the population and the sample chosen is representative enough. In terms of age, $16 \%$ of respondents were above 50 years old, the majority (51\%) were between 41 and 50 years old and only $33 \%$ of respondents were under 40 years of age. The fact that the majority (67\%) of respondents were older than 40 years old (i.e. born around the 1970s) and the oldest (16\%) of the participants were over 50 years old (i.e. born around the 1950s/60s) is an indication that the majority of the participants had more than ten years of teaching experience. In terms of qualification of the respondents, at least $42 \%$ of the respondents had acquired a post-matriculation qualification with three year diplomas in teaching and 39\% of the respondents had obtained a Bachelor's degree. Of these $39 \%$ with a Bachelor's degree, about $22 \%$ had obtained postgraduate qualifications on top of their teaching qualifications. These include 15\% who had Honours degrees and $4 \%$ whose qualifications were classified as "other". There was no one with a Master's or Doctoral degree. A large number of respondents (82\%) are ordinary teachers, (also known as level 1 or CS1 teachers) and about $10 \%$ are Heads of Departments (also known as CS2 teachers) as well as 8\% comprising Deputy Principals (CS3) and Principals (also known as CS4).

After receiving the appropriate authorisations from the participating school principals and the signed consent forms from the participants, the researcher proceded by personally hand-delivering all the questionnaires to each respondent at their work-places. Hand-delivering the questionnaires, prevented possible delays resulting from posting questionnaires and also helped to establish a good relationship between the researcher and the respondents. The researcher also did whatever possible to personally collect all the completed questionnaires directly from the respondents' hands in order to ensure anonymity and to avoid a situation in which third-party could access to the data collected by the researcher. Since the research design was mainly quantitative, the primary data collected was analysed quantitatively by use of the Statistical Package for the Social Sciences (SPSS), and various ways, namely tables and graphs, were used to present the results of primary data. The following Table 1summarises the sample composition per school, position, gender and race.

Table 1: Summary of respondents per participating schools

\begin{tabular}{|c|c|c|c|c|c|c|c|c|c|c|c|}
\hline \multirow[t]{2}{*}{$\begin{array}{l}\begin{array}{l}\text { Name of } \\
\text { schools }\end{array} \\
12 \text { schools }\end{array}$} & \multicolumn{2}{|c|}{$\begin{array}{l}\text { Number of } \\
\text { principals }\end{array}$} & \multicolumn{2}{|c|}{$\begin{array}{l}\text { Number of } \\
\text { teachers at } \\
\text { school }\end{array}$} & \multirow[t]{2}{*}{$\begin{array}{l}\begin{array}{l}\text { Racial } \\
\text { division }\end{array} \\
\text { Black }\end{array}$} & \multirow[t]{2}{*}{ Total } & \multicolumn{2}{|c|}{$\begin{array}{l}\text { Number of } \\
\text { teachers who } \\
\text { responded to } \\
\text { questionnaires } \\
\text { PER SCHOOL }\end{array}$} & \multicolumn{2}{|c|}{$\begin{array}{l}\text { Number of } \\
\text { principals who } \\
\text { responded to the } \\
\text { questionnaires } \\
\text { PER SCHOOL. }\end{array}$} & \multirow[t]{2}{*}{ TOTAL } \\
\hline & Male & Females & Male & Females & & & Male & Female & Male & Female & \\
\hline School A & 1 & - & 7 & 16 & 24 & 24 & 5 & 14 & $=$ & & 19 \\
\hline School 8 & & 1 & 4 & 4 & 9 & 9 & 4 & 4 & & 1 & 9 \\
\hline School C & 1 & - & 7 & 15 & 23 & 23 & 4 & 10 & - & & 14 \\
\hline School D & - & 1 & 3 & 5 & 9 & 9 & 3 & 2 & & - & 5 \\
\hline School E & 1 & - & 4 & 6 & 11 & 11 & 4 & 4 & 1 & & 9 \\
\hline School F & 1 & - & 8 & 4 & 13 & 13 & 7 & 4 & - & & 11 \\
\hline School G & 1 & - & 20 & 18 & 39 & 39 & 15 & 2 & - & & 17 \\
\hline School H & 1 & - & 10 & 4 & 15 & 15 & 7 & 5 & 1 & & 13 \\
\hline Schooli & 1 & - & 13 & 5 & 19 & 19 & 9 & 5 & - & & 14 \\
\hline Schools & 1 & - & 8 & 11 & 20 & 20 & 4 & 6 & - & & 10 \\
\hline School K & - & 1 & 5 & 3 & 9 & 9 & 2 & 3 & & 1 & 6 \\
\hline School L & 1 & - & 17 & 13 & 31 & 31 & 9 & 3 & - & & 12 \\
\hline SUB-TOTAL & 9 & 3 & 106 & 104 & 222 & 2222 & 73 & 62 & 2 & 2 & $139^{\circ}$ \\
\hline $\begin{array}{l}\text { SAMPLE } \\
\text { TOTAL }\end{array}$ & \multicolumn{6}{|c|}{7 respondents did not indicate their gender on the } & 73 & 62 & 2 & 2 & 146 \\
\hline
\end{tabular}

Table 1 created by the researcher 


\section{Findings and Discussions}

In line with this objective the data for this research was presented and analysed on the basis of availability and usage of ICT equipments at participating schools, ICT training for teachers, and the impact of ICT on teaching and learning in participating schools.

\subsection{Availability and usage of ict equipments at schools}

Before teachers can start intergrating ICT in their teaching and learning of students, the ICTs equipments must be first available at schools.

Figure 2: Availability of ICT in participating schools

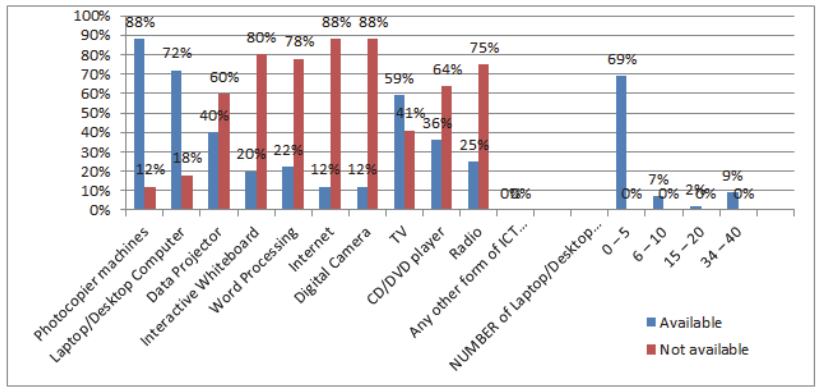

Figure 2 created by the researcher

Figure 2 above shows that the majority (88\%) of the respondents had photocopiers at their schools. This high prevalence may be because principals and School Management Team (SMT) need them for duplicating tests and exams papers, projects and assignments. However, there is evidence that some schools have photocopy machines but use them erratically, or never use them at all. For example, while $88 \%$ of the respondents reported having photocopy machines, only $62 \%$ of the respondents had used them regularly. The rest (38\%) swings between using them sometimes (19\%) and rarely or never used them at all (13\%). With regard to computers availability, Figure 2 shows that $72 \%$ of the respondents indicated that their schools had at least one computer available for them to use. The rest (12\%) indicated that they did not have any computers at school. However, an investigation into the use of these avalaible computers in produces dismal results. Figure 3 shows that only $32 \%$ of respondents of respondents who reported having computers at schools used computers regularly, $30 \%$ used them sometimes and about $68 \%$ had either sometimes/rarely or never used computers which are available at their schools (see Figure 3). The lack or insufficient use of computers could be partly attributed to the insufficient number of computers at schools which teachers have to share because, as the above Figure 2 shows, about $69 \%$ of schools have between zero and five computers. However, it is also possible that some teachers do not use computers which are available at their schools, simply because they do not have the necessary skills to use them. In addition, Figure 2 also indicates that $60 \%$ of the respondents did not have data projectors at their schools. The low level of availability of data projectors explains why as high as $61 \%$ of the respondents surveyed reported that they had rarely or never used a data projector. Figure 2 further indicates that $80 \%$ of respondents had no access to the Interactive Whiteboards at their schools. Once again, the fact that few schools have Interactive Whiteboards explains the low usage of this vital ICT equipment. The majority of the respondents (93\%) said they had rarely or never used an Interactive Whiteboard (see Figure 3).

Furthermore, Figure 2 above also indicates that the majority ( $88 \%$ of respondents) had no access to the Internet. This figure (88\%) correlates well with the findings in Figure 3 which shows that $84 \%$ of the respondents have rarely or never used internet at school. In an era where schools and teachers should be communicating electronically, the absence of Internet poses a serious problem. The implication is that principals have to travel to circuit offices to collect circulars - a waste of time and limited funds. Lack of internet also suggests that schools are forced to communicate with the outside world predominantly by post which is slow and unreliable. Figure 2 also shows that $88 \%$ of the respondents did not have digital cameras at their schools. This explains why $83 \%$ of the respondents in Figure 3 reported that they have rarely or never used any digital camera at their schools. Almost $60 \%$ of the teachers surveyed indicated that TV's were available at their schools. However, the analysis of the data suggests that those schools which had TV's and such equipment did not 
necessarily use them regularly. About $74 \%$ of the respondents reported to have rarely or never used TV and only $36 \%$ have used TV reguraly. The fact that a high percentage of the respondents indicated that TV was rarely or never used at school suggest that that educational programmes offered by South African Broadcasting Corporation (SABC) to support learners are not accessible and so learners are missing valuable information in subjects such as Mathematics and Science. The other simple, but vital ICT equipment missing at many schools that have participated in this research are CD/DVD players. As many as $64 \%$ of schools that participated in this research did not have access to CD/DVD players and about $60 \%$ of those who had them rarely or never used them (see Figure 3). Finally, dispite the fact that Radios are relatively cheap, user-friendly and, unlike TVs), radios could be operated even in remote places where there is no electricity; more than two-thirds of the respondents (75\%) indicated that radios were neither available nor used for teaching at their schools. Figure 3 summarises the respondents' views on how the ICT equipment was being used in their schools.

Figure 3: Usage of ICT equipment

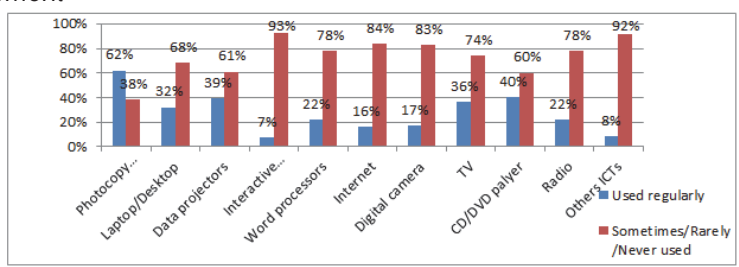

Figure 3 created by the researcher

\subsection{Training teachers to become ict proficient}

According to Galanouli, Murphy \& Gardner (2004:65), the importance of professional development for the successful uptake of ICT in the classroom attracts strong endorsement in the literature. According to Lawrence \& Veena (2013), ICTspecific fundamental skills include basic actions such as: managing electronic files, using computerised databases and spreadsheets, sending and receiving e-mail messages, and creating documents with graphics. However, these skills are only the prerequisites for more advanced skills, such as accessing online resources, creating desktop, publishing documents, developing multimedia presentations, selecting and customising instructional software to fit students' needs, streamlining record-keeping and other administrative procedures with electronic tools, and observing the correct protocols in sharing intellectual property (Lawrence \& Veena, 2013). The competencies are organised into five aspects: productivity, communication, research, media and presentation (ISTE, 2000).

a) Productivity: According to Lawrence \& Veena (2013), productivity may include composing standard educational publications such as parent newsletters and handouts for students and class lists, and teaching students how to prepare their own documents on a computer. Productivity also includes administrative work such as putting student test scores into a spreadsheet and analysing them, as well as preparing curriculum materials with digital tables and graphs of curriculum content. It also includes the ability to organise information graphically using specialised graphic organiser programs, as well as general tools such as word processors or presentation programs, to create digital representations of educational information (ISTE, 2000 cited in Lawrence \& Veena, 2013:2).

b) Research: In their professional preparation as well as in their classroom assignments, the teacher should be able to choose the most appropriate research tools and databases, and applies the most effective search techniques, to produce useful and safe online resources in the classroom. Teachers and students also need the skills to locate the sources of information and, once located, the teacher should know the difference between authoritative and untrustworthy sources, how to ascertain authorship, and how to find sources with different points of view. The teacher should be able to teach these skills to students (Lawrence \& Veena, 2013).

c) Communication: One of the basic and important skills teachers should have is the ability to communicate using digital tools. Teachers' skills should include email, instant messaging, mobile colleagues, and knowing how to organise and manage these tools in the classroom (ISTE, 2000). In addition, they should be able to collaborate online for learning in order to takes advantage of the tools such as blogs, wikis, chats, audio and videoconferencing, to bring outside resources into the classroom and to encourage academic collaboration among students (Lawrence \& Veena, 2013). 
d) Presentation: Teachers should be able to create effective digital presentations using common tools for preparing slide shows, videos and podcasts (ISTE, 2000). With these skills, teachers are expected to be able to create presentations that follow the principles of communication, and can apply these design principles to the evaluation of students' digital work. Once created, the teacher should be able to deliver digital multimedia presentations to students. Using common devices such as computers, projectors and screens, the teacher can set up classroom presentations and arrange for students to do the same (Lawrence \& Veena, 2013:2-3).

e) Media: The competencies in terms of electronic media require teachers to have the ability to:

- Differentiate instruction with digital media: This includes an awareness of assistive technologies for disabled students as well as the ability to use a computer to prepare and present academic ideas in a variety of forms for better learning by all students (ISTE, 2000).

- Capture and edit images, audio and video: The teacher can use digital and video cameras, edit their output on a computer, and produce learning materials that range from simple slide shows and are able to archive those for future use (Lawrence \& Veena, 2013:2-3).

- Produce digital multimedia educational experiences: With this competency, as Lawrence and Veena (2013:2-3) continue to argue, the teacher can combine media from a wide array of sources into a useful presentation of academic content, and can teach this skill to students,

- Employ new media devices for learning: From large Smartboards to tiny iPods to science probes, the teacher can incorporate a variety of digital devices into the instruction in the classroom (ISTE, 2000).

Those are the skills that just about every teacher needs to master, no matter the subject or grade. Beyond these are the more specific technical skills required of a high school math teacher or a teacher of visually-impaired students, competencies that would be embedded into specialised courses and programs (ISTE, 2000; Lawrence \& Veena, 2013:23). Clearly these skills can only be acquired if teachers are afforded the opportunity to acquire sufficient ICT training and continuous on-the-job training in order to keep up with ICT developments.

Thus, in conducting this research, the researcher focussed on finding out existing and current professional ICT qualifications, different types of ICT training the respondents have received, reason for undertaking ICT training, the number of years after they have taken an ICT training, and respondents' perceived impact on ICT training on the way they perform their work. The finding in this regard leaves much to be desired. For example, in terms of holding professional ICT qualifications, it was discovered that only $41 \%$ of the respondents had a professional ICT qualification (certificate, diploma etc.). Thus, the majority of respondents (59\%) did not have any ICT qualification. This is not to imply that not having an ICT qualification equates that a person has no knowledge about how to use ICT. However, the fact that the majority of the educators were in their late $40 \mathrm{~s}$ and the fact that the majority of the people surveyed did not have any professional ICT qualifications should be a serious cause for concern for the national and provincial Department of Education, but more specifically for the schools concerned because the majority of these educators may not have been able to use the ICT which was available to their schools. This age range could affect negatively the ability to use ICT because while "young people of today are undoubtedly growing up in a technological environment" this was not the case for their parents or most people who studied their primary and high school levels prior to mid-1990's (Mpinganjira \& Mbango, 2013:39).

However, perhaps the biggest problem is that most respondents who attended some ICT training courses said they were too basic and too short to make an impact on their ICT competencies. The result of the survey indicated that $59 \%$ of the respondents had received basic computer literacy training (on how to turn computer on/off, loading software etc.), instead of how to use computers to prepare slides or to download from the Internet any other course material they needed to teach. Only few respondents (7\%) had been trained on Electronic Communication Device (ECD) and computer integrations and $1 \%$ of respondents had been trained in programs such as Microsoft. The fact that the received training was not sufficient to equip teachers with five aspects of the necessary ICT competencies (productivity, communication, research, media and presentation) discussed above in this paper could explain why so few of the teachers who received ICT training were able to use ICT to teach their learners. Only $18 \%$ of the respondents said the ICT training they received benefited them and their learners while $82 \%$ found no link at all. It also explains why the majority (53\%) of the respondents reported that they had no confidence at all in the implementation of ICT in the classroom. These findings paint a gloomy picture because teachers who are not confident in using ICT are not likely to use it to improve their teaching and learning in the classroom. Furthermore, the researcher also wanted to probe the motivating factors behind those who decided to undertake ICT training. The findings also indicate that $(42 \%)$ of the respondents enrolled for computer training to increase career prospects while $34 \%$ of the respondents wanted computer skills for personal interest. Thus, a sizeable $77 \%$ of the respondents underwent computer training for reasons other than using their skills to 
improve teaching and learning. The fact that only $17 \%$ indicated that their training had been paid for either by the Department of Basic Education, the donor or the school highlight lack of support from school management and from the department of education. Lack of support and leadership from school management and from the department of education is also well demonstrated by the fact that only $6 \%$ of the respondents were required by the management of their schools to go for computer training.

\section{Cincluding Remarks and Recommandations}

As indicated at the beginning of this paper, the objective of this research was to to investigate the availability and effects of Information Communications Technology (ICT) on rural school teachers' ability to perform their teaching duties and the management of other curriculum-related activities. The analysis of the findings which focussed on the availability and usage of ICT equipments at participating schools, ICT training for teachers and the impact of ICT on teaching and learning in schools paints a very disappointing picture in the twelve participating high schools of the Groot Letaba Circuit. Literature and the analysis in this report have clearly demonstrated that any absence or shortage of ICTs and insufficient ICT training for teachers which is reported here has the potential of alienating teachers' abilities, confidence and attitude but also to compromise teaching and learning. The factors that negatively influence rural school teachers' readiness for, and confidence in, using ICT; need to be dealt with by the various stakeholders including, and especially, the Department of Education, the school management and private partners.

\section{References}

Allan, H.K. Yuen, N.L. \& Wong, K.C. (2003). ICT implementation and school leadership: Case studies of ICT integration in teaching and learning. Journal of Educational Administration, vol.41, No. 2, pp. 158-170.

Ayemoba, A. (2013). New Limpopo ICT resource centre to boost teacher training in Maths and Science. Available from: Southafricabusinesscommunities.com/profiles/blog/new-limpopo-ict-resource-centre-to-boost-teacher-training-in (Accessed: 19 August 2013).

Babooa, S. K. (2008). Public participation in the making and implementation of policy in Mauritius with reference to Port Louis' Local Government. Unpublished Doctoral thesis. Pretoria: University of South Africa.

Balanskat, A. (2007). Study of the impact of technology in primary schools. Final Report. http://eacea.ec.europa.eu/lip/studies/ documents/study_impact_technology_primaryschool/3_literature_review_steps_en.pdf (Accessed: 3 December 2013).

Beyers, R. (2000). The Quality Ëdge. ICT learning opportunities. Management Today, vol. 16.

Bialobrzeska, M. \& Cohen, S. (2005). Managing ICTs in South African schools. A guide for school principals. SAIDE. http://www.education.gov.za/LinkClick.aspx?fileticket=4rn8m810sXw\%3D\&tabid=452\&mid=1036 (accessed: 17 March 2014).

Bingimlas, K.A. (2009). Barriers to the Successful Integration of ICT in Teaching and Learning Environments: A Review of the Literature, Eurasia Journal of Mathematics, Science \& Technology Education, 2009, vol. 5(3):235-245.

Buabeng-Andoh, C. 2012. Factors influencing teachers' adoption and integration of information and communication technology into teaching: A review of the literature, International Journal of Education and Development using Information and Communication Technology(IJEDICT), 2012, Vol. 8, Issue 1, pp. 136-155.

Cohen, L., Manion, L. \& Morison, K. (2000). Research Methods in Education (5th ed.) (Routledge Falmer).

Department of Communications. (2013). Proposed ICT Policy Review Framing Paper. Government Gazette No. 36408. Pretoria

Devadason, R.P. (2010). The State of use of ICT in the Teaching and Learning of Science and Mathematics among schools in SEAMEO Member Countries. Seameo Recsam.

DoE, (2003). Draft White Paper on e-Education Transforming Learning and Teaching through ICT. http://www.gov.za/documents/ download.php?f=68777.(accessed: 18 March 2014).

ELRC Annual Report. (2010/11). Presentation to Parliament 13 October 2011. http://d2zmx6mlqh7g3a.cloudfront.net/cdn /farfuture/0ayhWlzEHTwmBnlhNjBVu86uHETcuMG_nxqdtmzP5DE/mtime:1381177837/files/docs/111013elrc.pdf (Accessed: 28 November 2013)

ELRC (2010). ELRC Report - Teacher Laptop Initiative, Government Gazette - Cape Town. Parliamentary Monitoring Group.

Evoh, C.J. (2007). ICTs, Secondary Education, and the Knowledge Economy: Exploring the Roles of the Private Sector in PostApartheid South Africa. Journal of Education for International Development.3:1.

Farrell, G. \& Isaacs, S. (2009). Beyond primary Education: Challenges and Approaches to Expanding Learning Opportunities, Survey of ICT and Education in Africa, vol.1, May 5-9, 2009.

Forsyth, I. (1996). Teaching and Learning Materials and the Internet. London: Kogan Page.

Galanouli, D., Murphy, C. \& Gardner, J. (2004). Teachers' perceptions of the effectiveness of ICT-competence training. Computers \& Education, 43 (2004), pp. 63-79.

Goyal, E., Purohit, S. \& Bhaga, M. (2011). Study of satisfaction and usability of the Internet on students' performance. International journal of education and development using information and communication technology (IJEDICT), 2011, vol. 1, No. 1.

Howie, S.J., Muller, A. \& Paterson, A. (2005). Information Communication Technologies in South African Secondary Schools. Cape Town: Sites (HRSC Press). 
Isaacs, S. (2007). Survey of ICT and education in Africa: South Africa Country Report South Africa - 1. www.infodev.org (accessed: 17 March 2014).

ISTE. (2000). National EducationalTechnology Standards (NETS) for teachers. http://cnets.iste.org/index3.html (Accessed: 25 November 2013).

Kargiban, Z.A. \& Siraj, S. (2009). The utilisation and Integrating of ICT in Chemistry Teaching in Iranian High Schools. World Applied Sciences Journal 6(11): 1447-1456.

Korte, W.B. \& Hüsing, T. (2007). Benchmarking access and use of ICT in European schools 2006: Results from Head Teacher and A Classroom Teacher Surveys in 27 European countries, eLearning Papers 2, 1: 1-6 www.elearningeuropa.info/files/media Imedia11563.pdf (accessed: 18 March 2014).

Kozma, R.B. (2003). Technology and Classroom Practices: An International Study. Journal of Research on Technology in Education, Fall 2003, vol. 36, No. 1.

Kruger, J. (2010), "Latest ICT Trends in Enhancing Education", Department of Informatics, University of Pretoria, Pretoria, South Africa, available at: http://web.up.ac.za/ecis/sacla2010pr/sacla2010/papers/sacla029.pdf (accessed 8 March 2012).

Kulik, J.A. (1994).Meta-analytic studies of findings on computer-based instruction. In J.E.L. Baker \& H.F.

O'Neil (Ed.), Technology Assessment in Education and Training. Hillsdale, NJ: Lawrence Erlbaum.

Lawrence, A.S. \& Veena, K. (2013). Improving teacher competency through ICT. http://www.academia.edu/1462066/ICT_AND_ TEACHER COMPETENCIES (Accessed: 25 November 2013).

Makewa, L., Meremo, J., Role, E. \& Role, J. (2013). ICT in secondary school administration in rural southern Kenya: An educator's eye on its importance and use. International Journal of Education and Development using Information and Communication Technology (IJEDICT), 2013, vol. 9, No. 2, pp. 48-63.

Maluleka, S. (2011). Bad credit bytes teachers. Available from: http://www.iol.co.zal dailynews/news/bad-credit-bytes-teachers1.1122476?ot=inmsa.ArticlePrintPageLayout.ot (accessed: 22 November 2013).

Mdletshe, C. (2013). School overcrowding at 'alarming' levels, http://www.timeslive.co.za/thetimes/2013/02/12/school-overcrowding-atalarming-levels (accessed: 16 May 2014).

Mikre, F. (2011). The Roles of ICT in Education. Review Article with Emphasis to the computer and Internet. Ethiopian Journal of Education and Science, vol. 6, No. 2.

Miller, L., Naidoo, M \& van Belle, J. (2006). Critical Success Factors for ICT Interventions in Western Cape Schools. Department of Information Systems: University of Cape Town

Mpinganjira, M \& Mbango, P. (2013). Profiling non-users of e-government services: in quest of e-government promotion strategies. Journal of Global Business and Technology, Volume 9, Number 2, Fall 2013.

Mugo, F.W. (2002). Sampling In Research. Available from: https://profiles.uonbi.ac.ke/fridah_mugo/files/mugo02sampling.pdf (Accessed: 5 December 2013).

Naseri, M. \& Elliott, G. (2011). Role of Demographics, Social Connectedness and Prior Internet Experience in Adoption of Online Shopping: Applications for Direct Marketing. Journal of Targeting, Measurement and Analysis for Marketing, 19(2):69-84.

Newton, L. \& Rogers, L. (2001). Teaching Science with ICT. New York: Continuum.

Ngcaba, A. (2012). Building a Digital Life For All South Africans - Building an ICTecosystem through an inclusive consultative process. Paper presented at the Department of Communications Policy Colloquium (accessed: 22 January 2014).

NPC. (2011). Nationa Deveopment Plan: Vision for 2030. http://www.npconline.co.za/medialib/downloads/home/NPC\%20National\% 20Development\%20Plan\%20Vision\%202030\%20-lo-res.pdf (accessed: 17 March 2014).

Oladosu, K. (2012). Basic Technology Teachers' Awareness and Attitude Towards the Use Of Information and Communication Technology For Sustainable Development in Lagos State Education Districts: I, IV and VI. Journal of Education and Practice, Vol 3, № 13, 2012.

Perron, B.E., Taylor, H.E., Glass, J.E. \& Margerum-Leys, J. (2010). Information and Communication Technologies in Social Work. Advances in Social Work, vol. 11, No. 1 (Spring 2010), pp. 67-81.

Riel, M. (2000). The future of technology and education: Where are we heading? In Watson,

D. M. \& Downes, T. (Eds.) Communications and Networking in Education, Boston, MA: Kluwer Academic Press, pp 9-24.

Rwanda Ministry of Education. (2008). ICT in Education Policy. http://planipolis.iiep.unesco.org/upload/Rwanda/Rwanda_ICT_policy.pdf (accessed: 18 March 2014).

SAITIS. (2002). Review of policies impacting the ICT Sector: policy and legislative review. Z Coms. http://www.trigrammic.com/downloads/Review\%20of\%20Policies\%20impacting\%20the\%20ICT\%20Sector.pdf (accessed:18 March 2014).

Summak, M.S. \& Samancioglu, M. (2011). Assessment of technology integration in vocational education and training schools. International journal of education and development using information and communication technology (IJEDICT), vol.1, No.1.

Tubbs, B. (2013). Teacher Laptop Initiative mired. Available from:http://www.itweb.co.za/index.php?option=com _content\&view= article\&id=61280 (Accessed: 22 November 2013).

Van Ark, B. (2011). Economic and Social Benefits of ICT: Presentation for Conference on "Fibre networks: Demand and analyses of costs and benefits. The conference Board. http://www.wik.org/c80bd74c-6628-40c5-907d6c6f7475be16/finaldownload/downloadid-4b2f53761292d6143ba2a244183ea160/c80bd74c-6628-40c5-907d6c6f7475be16/fileadmin/konferenzbeitraege/2011/fibre_network/van_ark.pdf (accessed:: 25 November 2013).

Van Rij, V. \& Warrington, B. (2010). Teaching and Learning for an ICT revolutionised society. The results of a Foresight Workshop organised as part of the FP7 Blue Skies Project FarHorizon 2-3 December 2010, Brussels.

Wheeler, S. (2000). The Role of the Teacher in the Use of ICT. Keynote Speech delivered to the National Czech Teachers Conference. University of Western Bohemia, Czech Republic. Learning Technology Research. 